\title{
PENGARUH MODEL PEMBELAJARAN BERBASIS MASALAH TERHADAP PEMAHAMAN KONSEP DAN BERPIKIR KRITIS SISWA SMP NEGERI 4 BEBANDEM
}

\author{
M. Ayu Ratna Parwathi, W. Santyasa, W. Warpala \\ Program Studi Teknologi Pembelajaran, Program Pascasarjana, \\ Universitas Pendidikan Ganesha, Singaraja, Indonesia. \\ Email: ratna.parwathi@pasca.undiksha.ac.id, \\ wayan.santyasa@pasca.undiksha.ac.id, sukra.warpala@pasca.undiksha.ac.id
}

\begin{abstract}
Abstrak
Penelitian ini bertujuan untuk mendeskripsikan (1) perbedaan pemahaman konsep IPA dan keterampilan berpikir kritis siswa antara yang belajar dengan model pembelajaran berbasis masalah dengan yang belajar dengan model pembelajaran konvensional, (2) perbedaan pemahaman konsep IPA antara yang belajar dengan model pembelajaran berbasis masalah dengan yang belajar dengan model pembelajaran konvensional, (3) perbedaan keterampilan berpikir kritis siswa antara yang belajar dengan model pembelajaran berbasis masalah dengan yang belajar dengan model pembelajaran konvensional. Penelitian eksperimen semu ini dengan mengambil populasi 5 kelas siswa kelas VII SMP Negeri 4 Bebandem, Karangasem Tahun Pelajaran 2015/2016. Sampel ditentukan dengan teknik Group Random Sampling. Berdasarkan hasil random, terpilih kelas VIIA menggunakan model pembelajaran PBL dan Kelas VIID dengan model pembelajaran konvensional. Data pemahaman konsep IPA dan keterampilan berpikir kritis dikumpulkan dengan tes. Data dianalisis secara diskriptif dan analisis multivariate analysis of covariance (MANCOVA).

Hasil penelitian menunjukkan bahwa: (1) terdapat perbedaan signifikan pemahaman konsep IPA dan keterampilan berpikir kritis siswa antara yang belajar dengan model pembelajaran berbasis masalah dengan yang belajar dengan model pembelajaran konvensional, pemahaman konsep IPA dan keterampilan berpikir kritis siswa yang menggunakan model pembelajaran berbasis masalah lebih baik dibandingkan dengan pemahaman konsep IPA dan keterampilan berpikir kritis siswa yang menggunakan model konvensional; (2) terdapat perbedaan signifikan pemahaman konsep IPA antara yang belajar dengan model pembelajaran berbasis masalah dengan yang belajar dengan model pembelajaran konvensional, pemahaman konsep IPA yang menggunakan model pembelajaran berbasis masalah lebih baik dibandingkan dengan pemahaman konsep IPA yang menggunakan model pembelajaran konvensional; (3) terdapat perbedaan signifikan keterampilan berpikir kritis siswa antara yang belajar dengan model pembelajaran berbasis masalah dengan yang belajar dengan model pembelajaran konvensional, keterampilan berpikir kritis siswa yang menggunakan model pembelajaran berbasis masalah lebih baik dibandingkan dengan keterampilan berpikir kritis siswa yang menggunakan model pembelajaran konvensional.
\end{abstract}

Kata Kunci: pembelajaran berbasis masalah, pemahaman konsep IPA, keterampilan berpikir kritis.

\begin{abstract}
This study aimed to describe (1) differences in understanding the concept of science and critical thinking skills of students between learners and problem based learning with learning with conventional learning models, (2) differences in understanding the concept of science among learners and problem based learning model with the learning with conventional learning models, (3) the difference between the critical thinking skills students are learning with problem based learning with learning with conventional learning models. This quasi-experimental research by taking a class 5 student population of class VII SMP Negeri 4 Bebandem, Karangasem in the academic year 2015/2016. The sample is determined by the Group Random Sampling technique. Based on the results of random, elected class VIla using PBL learning model and Class VIID with conventional learning models. Data understanding of the concept of science and critical thinking skills are collected by the test. Data were analyzed by descriptive and multivariate analysis of covariance analysis (MANCOVA).
\end{abstract}


The results showed that: (1) there is a significant difference in understanding the concept of science and critical thinking skills of students between learners and problem based learning with learning with conventional learning models, understanding the concept of science and critical thinking skills of students using problem based learning model more compared with the understanding of the concept of science and critical thinking skills of students who use the conventional model; (2) there is a significant difference between the understanding of the concept of science learning with problem based learning with learning with conventional learning models, understanding the concept of science that uses problem-based learning model is better than the understanding of science concepts that use conventional learning model; (3) there is a significant difference in critical thinking skills of students between learners and problem based learning with learning with conventional learning models, critical thinking skills students use problem based learning model is better than the critical thinking skills of students who use conventional learning models.

Keywords: problem-based learning, understanding science concepts, critical thinking skills.

PENDAHULUAN

Pendidikan adalah salah satu bentuk perwujudan kebudayaan manusia yang dinamis dan sarat perkembangan. Oleh karena itu, perubahan atau perkembangan pendidikan adalah hal yang memang seharusnya terjadi sejalan dengan perubahan budaya kehidupan. Perubahan dalam arti perbaikan pendidikan pada semua tingkat perlu terus-menerus dilakukan sebagai antisipasi kepentingan masa depan. Pendidikan yang mampu mendukung pembangunan dimasa mendatang adalah pendidikan yang mampu mengembangkan potensi siswa, sehingga mampu menghadapi dan memecahakan problema kehidupan yang dihadapi. Pendidikan harus menyentuh potensi nurani maupun kompotensi siswa, hal tersebut terasa semakin penting ketika siswa harus memasuki kehidupan dimasyarakat dan dunia kerja. Siswa harus mampu menerapkan apa yang dipelajari di sekolah untuk menghadapi problema dalam kehidupan sehari-hari maupun yang akan datang. Pendidikan senantiasa menjadi sorotan bagi masyarakat, khususnya pendidikan di sekolah menengah yang terus mengadakan pembaharuan.

Paradigma dalam proses pembelajaran diharapkan mengalami perubahan, proses pembelajaran yang cenderung berpusat pada guru (teacher centered) berubah menjadi berpusat pada siswa (student centered). Untuk Perubahan ini paradigma pembelajaran tersebut diharapkan dapat mendorong siswa agar terlibat aktif dalam membangun pengetahuan. Kegiatan inti pembelajaran di kelas meliputi proses eksplorasi, elaborasi, dan konfirmasi.

Dalam proses pembelajaran diharapkan adanya perubahan atau inovasi -inovasi yang mengarah pada kemajuan dalam ilmu pengetahuan, salah satunya dengan penerapan ilmu teknologi pembelajaran di sekolah. Tujuan utama teknologi pembelajaran adalah untuk 
memecahkan masalah belajar atau memfasilitasi kegiatan pembelajaran. Teknologi pembelajaran sebagai perangkat lunak (software technology) yang berbentuk cara-cara yang sistematis dalam memecahkan masalah pembelajaran semakin canggih dan mendapat tempat secara luas dalam dunia pendidikan (Suparman \& Zuhairi, 2004:345-346). Dengan demikian, aplikasi praktis teknologi pembelajaran dalam pemecahan masalah belajar mempunyai bentuk konkret dengan adanya sumber belajar yang memfasilitasi peserta didik untuk belajar.

Sumber daya manusia yang berkualitas sangat diperlukan agar suatu bangsa mampu bersaing dan berkompetisi dengan bangsa lain. Mata pelajaran IPA merupakan disiplin ilmu yang bersifat khas, salah satu kekhasannya adalah memuat konsep-konsep yang bersifat abstrak, namun sesungguhnya IPA sangat erat hubungannya dengan kehidupan sehari-hari. Pendidikan IPA merupakan salah satu sektor penting dalam menghasilkan SDM yang kompetitif dan memiliki daya saing. Guru di dalam melaksanakan proses pembelajaran selalu berpedoman pada kurikulum yang digunakan untuk mencapai keberhasilan pembelajaran.

Rendahnya pemahaman konsep dan keterampilan berpikir kritis siswa pada mata pelajaran IPA kelas VII SMP Negeri
4 Bebandem, yang disebabkan oleh aktivitas siswa yang menurun dalam belajar. Hal ini diduga antara lain dipengaruhi oleh model pembelajaran yang selama ini digunakan oleh guru yang kurang inovatif dan kurang bervariasi. Pemilihan model pembelajaran yang sesuai dengan tujuan kurikulum dan potensi siswa merupakan kemampuan dan keterampilan dasar yang harus dimiliki oleh seorang guru. Hal ini didasari oleh asumsi bahwa ketepatan guru dalam memilih metode pembelajaran akan berpengaruh terhadap keberhasilan dan hasil belajar siswa.

Belajar merupakan proses perkembangan kearah yang lebih sempurna, belajar sebagai konstruksi pengetahuan oleh peserta didik sendiri berdasarkan hasil interaksinya dengan lingkungan (Santyasa, 2011). Secara umum, terdapat lima konsepsi tentang belajar yaitu: (1) belajar sebagai penguatan respon, (2) belajar sebagai pemerolehan pengetahuan, (3) belajar sebagai konstruksi pengetahuan, (4) penerapan pengetahuan secara bermakna, (5) pembiasaan berpikir efektif dan produktif.

Landasan filosofi pendekatan kontekstual adalah konstruktivisme, bahwa pengetahuan bukanlah seperangkat fakta-fakta, konsep, atau kaidah yang siap untuk diambil dan diingat, tetapi pengetahuan dibangun oleh manusia itu sendiri. Implikasi dari 
pandangan konstruktivisme adalah pengetahuan tidak dapat dipindahkan secara utuh dari pikiran pebelajar ke pikiran pebelajar, tetapi pengetahuan dapat dibangun dalam pikiran pebelajar.

Dzaki (2009) menyatakan Teori Belajar Konstruktivis merupakan salah satu landasan teoretik pendidikan IPA modern termasuk pembelajaran dengan pendekatan kontekstual (Contextual Teaching and Learning/CTL).

Untuk meningkatkan pemahman konsep dan berpikir kritis siswa maka dipilih model pembelajaran yang menganut paham kontrukstivisme.

Model pembelajaran yang menganut paham kontrukstivisme adalah model pembelajaran berbasis masalah (PBL). Pembelajaran berbasis masalah $(P B L)$ memiliki karakteristik-karakteristik sebagai berikut: (1) belajar dimulai dengan suatu permasalahan, (2) memastikan bahwa permasalahan yang diberikan berhubungan dengan dunia nyata pebelajar, (3) mengorganisasikan pelajaran di seputar permasalahan, bukan di seputar disiplin ilmu, (4) memberikan tanggung jawab sepenuhnya kepada pebelajar dalam mengalami secara langsung proses belajar mereka sendiri, (5) menggunakan kelompok kecil, dan (6) menuntut pebelajar untuk mendemontrasikan apa yang telah mereka pelajari dalam bentuk produk atau kinerja (performance) (Santyasa, 2012).
Penyelidikan autentik, model pembelajaran berbasis masalah ( $P B L$ ) menghendaki siswa untuk melakukan penyelidikan autentik untuk mencari penyelesaian nyata terhadap masalah nyata. Mereka harus menganalisis dan mendefinisikan masalah mengembangkan hipotesis dan membuat ramalan, mengumpulkan dan menganalisis informasi, melakukan eksperimen (jika diperlukan), membuat interferensi, dan merumuskan kesimpulan. Menghasilkan produk/karya dan memamerkannya.

Proses pembelajaran dengan model problem-based learning dijalankan dengan 8 langkah, yaitu: (1) menemukan masalah, (2) mendefinisikan masalah, (3) mengumpulkan fakta-fakta, (4) menyusun dugaan sementara, (5) menyelidiki, (6) menyempurnakan permasalahan yang telah didefinisikan, (7) menyimpulkan alternatif-alternatif pemecahan secara kolaboratif, (8) menguji solusi permasalahan (Fogarty, 1997).

Pemahaman konsep menduduki posisi strategis dalam suatu taksonomi pembelajaran (instructional taxonomies). Menurut taksonomi Bloom (Costa, 1985) dari level paling bawah ke level paling atas adalah: knowledge, comprehention, application, analysis, sintesis, dan evaluation. Pemahaman berada pada level comprehention menurut taksonomi Bloom, verbal information menurut taksonomi Gagne, meaningful learning menurut taksonomi Ausubel, declarative 
knowledge menurut taksonomi, remember parapheased menurut taksonomi Meril dan pada level understand relationsips menurut taksonomi Reigeluth (Reigeluth \& Moore, dalam Santyasa, 2004). Pemaparan tersebut mengindikasikan bahwa pemahaman memerlukan prasyarat pengetahuan pada level yang lebih rendah dan merupakan prasyarat pengetahuan pada level yang lebih tinggi, baik pada konteks yang sama maupun pada konteks yang berbeda. Pemahaman konsep adalah kemampuan aktual yang dicapai oleh siswa setelah siswa tersebut mengalami suatu proses belajar mengenai konsep, prinsip, dan prosedur IPA. Pemahaman konsep adalah sama dengan tingkatan C2 dalam ranah kognitif taksonomi Bloom.

Berdasarkan uraian diatas, model pembelajaran berbasis masalah penting untuk diselidiki pengaruhnya terhadap pemahaman konsep IPA dan berpikir kritis siswa. Penelitian ini hakekatnya adalah bertujuan untuk Mendeskripsikan perbedaan pemahaman konsep IPA dan keterampilan berpikir kritis antara siswa yang belajar dengan menggunakan model pembelajaran berbasis masalah (PBL) dan siswa yang belajar dengan model konvensional, setelah perlakuan di kontrol dengan kovariabel pemahaman konsep IPA dan keterampilan berpikir kritis. METODE PENELITIAN

Penelitian ini merupakan penelitian quasi experiment karena tidak memungkinkan untuk melakukan seleksi subjek secara acak. Berdasarkan jenis penelitian yang dipilih, desain yang digunakan dalam penelitian ini adalah Non Equivalent Pretest-Posttest Control Group Design

Populasi penelitian ini adalah semua kelas VII SMP Negeri 4 Bebandem Tahun Pelajaran 2015/2016, yang terdiri dari 5 kelas, diambil sebagai sampel hanya 2 kelas, berjumlah 46 orang, yang terdiri dari 23 orang tiap kelas, pengambilan sampel dilakukan dengan teknik Group Random Sampling, di mana kelas yang muncul dalam undian langsung dijadikan kelas sampel. Dari 5 kelas populasi selanjutnya dipilih hanya dua kelas sebagai kelas sampel. Dua kelas tersebut diundi kembali sehingga diperoleh kelas VIIA mendapat perlakuan model pembelajaran berbasis masalah (PBL) dan kelas VIID dengan model konvensional.

Yang merupakan variabel pada penelitian ini adalah

1) Variabel bebas (independent variable) merupakan variabel yang menyebabkan atau mempengaruhi, yaitu faktor-faktor yang diukur, dimanipulasi atau dipilih oleh peneliti untuk menentukan hubungan antara fenomena yang diobservasi atau diamati. Variabel bebas dalam penelitian ini adalah model pembelajaran yang memiliki 2 
dimensi, yaitu model pembelajaran berbasis masalah dan model konvensional.

2) Variabel terikat (dependent variable) merupakan faktor-faktor yang diobservasi dan diukur untuk menentukan adanya pengaruh variabel bebas, yaitu faktor yang muncul, atau tidak muncul, atau berubah sesuai dengan yang diperkenalkan oleh peneliti. Pada penelitian ini variabel terikat yang digunakan terdiri dari dua dimensi yaitu pemahaman konsep IPA dan keterampilan berpikir kritis.

3) Kovariabel merupakan variabel yang mengendalikan secara statistik terhadap variabel lain dalam penelitian. Pada penelitian ini, yang digunakan sebagai kovariabel adalah data pemahaman konsep awal dan keterampilan berpikir kritis awal.

Data yang dikumpulkan dalam penelitian ini meliputi: (1) pemahaman konsep IPA dan (2) keterampilan berpikir kritis siswa yang dikumpulkan dengan metode tes.

1) Tes Pemahaman Konsep IPA

Tes pemahaman konsep IPA yang dikembangkan dalam penelitian ini adalah tes pilihan ganda diperluas. Tes ini harus menuntut siswa berpikir tentang alasan mengapa memilih jawaban yang benar (Santyasa, 2003).

Langkah-langkah dalam menyusun instrumen tes pemahaman konsep IPA meliputi: (1) mengidentifikasi standar kompetensi dan kompetensi dasar; (2) mengidentifikasi dan memaparkan indikator pencapaian siswa; (3) menyusun kisi-kisi (blue print) tes pemahaman konsep IPA; (4) menentukan kriteria penilaian; (5) menyusun butir-butir tes pemahaman konsep IPA; (6) uji ahli yaitu validitas isi dengan dua orang dosen dan seorang guru IPA; (7) uji coba instrumen di lapangan; (8) analisis uji lapangan; (9) revisi butir; dan (10) finalisasi instrumen.

Knedler (dalam Suada, 2008) menyatakan adapun kreteria penilaian didasarkan pada rubrik penilaian yang dirancang oleh peneliti. Pengembangan rubrik penilaian didasarkan pada tuntutan jawaban yang mencerminkan pemikiran secara tertulis/verbal yang menginterprestasikan ide-ide yang logis. Kreteria penilaian tes pemahaman konsep untuk tipe pilihan ganda diperluas dengan pemberian skor 0-4.

Tes yang dikembangkan dalam penelitian ini berbentuk tes esai/uraian. Tes esai/uraian dipilih dengan asumsi bahwa dengan menjawab tes esai/uraian, keterampilan berpikir kritis siswa lebih mudah diamati dibandingkan dengan menjawab tes obyektif. Penggunaan tes esai/uraian ini dapat menumbuhkan kemampuan berpikir divergen siswa. Penilaian keterampilan berpikir kritis 
berupa skor yang dicapai siswa, setiap butir tes memiliki rentangan 0-5.

Teknik analisis varian yang digunakan analisis multivariate MANCOVA (Multivariat Analysis of Covarian) satu jalur yang melibatkan satu variabel bebas dan dua variabel terikat. MANCOVA mengasumsikan bahwa data berasal dari populasi yang berdistribusi normal dan kelompok-kelompok yang dibandingkan homogen. Uji asumsi yang digunakan untuk analisis di antaranya: uji normalitas, uji homogenitas data, uji homogenitas matriks varian/covarians, uji linieritas, dan uji kolinearitas antar variabel dependen. Program yang digunakan SPSS-PC 16.0 for Windows. Pengujian hipotesis pada taraf $5 \%$.

\section{HASIL DAN PEMBAHASAN}

Penelitian ini memaparkan dua hal, meliputi: (1) deskripsi umum hasil penelitian, (2) analisis data serta pengujian hipotesis.

Rata-rata pemahaman konsep IPA siswa yang belajar dengan menerapkan model pembelajaran berbasis masalah adalah 54,43. Hal ini menunjukkan bahwa pemahaman konsep siswa yang belajar dengan menerapkan model pembelajaran berbasis masalah di SMP Negeri 4 Bebandem berkategori tinggi $(46,65 \leq \bar{X}<$ 59,90).

Rata-rata skor pemahaman konsep siswa yang belajar dengan menerapkan model pembelajaran konvensional adalah 49,34. Hal ini menunjukkan bahwa pemahaman konsep IPA siswa yang belajar dengan menerapkan model pembelajaran konvensional di SMP Negeri 4 Bebandem berkategori tinggi $(46,65 \leq \bar{X}<59,90)$.

Rata-rata keterampilan berpikir kritis siswa yang belajar dengan menerapkan model pembelajaran berbasis masalah (PBL) adalah 43,34 . Hal ini menunjukkan bahwa keterampilan berpikir kritis siswa yang belajar dengan menerapkan model pembelajaran berbasis masalah di SMP Negeri 4 Bebandem berkategori sedang $(31,25 \leq \bar{X}<43,75)$.

Rata-rata keterampilan berpikir kritis siswa yang belajar dengan menerapkan model pembelajaran konvensional adalah 38,13. Hal ini menunjukkan bahwa keterampilan berpikir kritis siswa yang belajar dengan model pembelajaran konvensional di SMP Negeri 4 Bebandem berkategori sedang $(31,25 \leq$ $\bar{X}<43,75)$.

Analisis data penelitian dilakukan setelah semua uji asumsi terpenuhi. Uji asumsi yang digunakan untuk analisis diantaranya: uji normalitas, uji homogenitas data, uji homogenitas matriks varian/covarians, uji linieritas, dan uji kolinearitas antar variabel dependen .

Hasil pengujian normalitas berdasarkan nilai-nilai statistik Kolmogorov-Smirnov Test dapat dilihat bahwa taraf signifikansi adalah 0,200, 
yang berarti bahwa taraf signifikansi lebih besar dari 0,05 (sig > $\alpha$ ). Jadi dapat disimpulkan bahwa $\mathrm{H}_{0}$ diterima dan $\mathrm{H}_{1}$ ditolak. Artinya, sebaran data pada kedua sampel berdistribusi normal.

Uji homogenitas dimaksudkan untuk memperlihatkan bahwa dua atau lebih kelompok sampel data berasal dari populasi yang memiliki varian yang sama. Uji homogenitas varian antarkelompok ini dapat dilakukan dengan menggunakan Levene's test of equality of error variance. dapat dilihat bahwa taraf signifikansi pemahaman konsep pada based on mean yaitu 0,562 lebih dari $0,05(\mathrm{sig}>\alpha)$. Dapat disimpulkan bahwa $\mathrm{H}_{0}$ diterima dan $\mathrm{H}_{1}$ ditolak. Artinya, semua kelompok data memiliki varians yang sama atau homogen pada pemahaman konsep. Pada keterampilan berpikir kritis siswa pada based on mean yaitu 0,799 , lebih dari 0,05 (sig $>\alpha$ ). Dapat disimpulkan bahwa $\mathrm{H}_{0}$ diterima dan $\mathrm{H}_{1}$ ditolak. Artinya, semua kelompok data juga memiliki varians yang sama atau homogen pada keterampilan berpikir kritis .

Uji homogenitas matriks varianskovarians sebagai syarat sebelum melakukan analisis MANCOVA dilakukan dengan menggunakan uji Box's Test of Equality of Covariance Matrices. hasil uji matriks varians-kovarians pada data pemahaman konsep dan keterampilan berpikir kritis menunjukkan angka Box's $M$ sebesar 0,458, nilai $F$ sebesar 0,145 dan angka signifikansi sebesar 0,933.
Mengingat angka signifikansi lebih besar dari 0,05 maka dapat disimpulkan bahwa matriks varians-kovarians antarvariabel pemahaman konsep dan keterampilan berpikir kritis adalah homogen.

Uji linieritas pengujian keberartian arah regresi dilakukan dengan menguji hipotesis nol $\left(\mathrm{H}_{0}\right)$ yang menyatakan bahwa koefisien arah regresi tidak berarti melawan hipotesis alternatif $\left(\mathrm{H}_{1}\right)$ yang menyatakan bahwa koefisien arah regresi berarti atau signifikan. Pada hasil analisis pemahaman konsep IPA pada tabel Anova di atas diperoleh nilai $F$ Liniearity besarnya 1,402 dengan nilai signifikansi 0,031 . Hasil signifikansi yang diperoleh lebih kecil dari signifikansi yang ditetapkan sebesar $\alpha=0,05$, ini berarti $\mathrm{H}_{0}$ ditolak dan $\mathrm{H}_{1}$ diterima. Artinya, koefisien arah regresi adalah signifikan.

Pengujian linieritas dilakukan dengan menguji $\mathrm{H}_{0}$ yang menyatakan bentuk regresi linier, melawan $\mathrm{H}_{1}$ yang menyatakan bentuk regresi tidak linier. dengan memperhatikan nilai $F$ Deviation from Linearity sebesar 0,472 dan nilai signifikansi sebesar 0,941. Signifikansi yang diperoleh lebih besar dari signifikansi $\alpha=0,05$. Dengan demikian $H_{0}$ diterima dan $\mathrm{H}_{1}$ ditolak. Artinya, bentuk regresi pemahaman konsep IPA adalah linier.

Pengujian keberartian arah regresi dilakukan dengan menguji hipotesis nol $\left(\mathrm{H}_{0}\right)$ yang menyatakan bahwa koefisien arah regresi tidak berarti melawan hipotesis alternatif $\left(\mathrm{H}_{1}\right)$ yang menyatakan 
bahwa koefisien arah regresi berarti atau signifikan. Pada hasil analisis keterampilan berpikir kritis pada tabel Anova di atas diperoleh nilai $F$ Liniearity besarnya 3,447 dengan nilai signifikansi 0,042 . Hasil signifikansi yang diperoleh lebih kecil dari signifikansi yang ditetapkan sebesar $\alpha=0,05$, ini berarti $\mathrm{H}_{0}$ ditolak dan $\mathrm{H}_{1}$ diterima. Artinya, koefisien arah regresi adalah signifikan. dengan memperhatikan nilai F Deviation from Linearity sebesar 0,908 dan nilai signifikansi sebesar 0,569. Signifikansi yang diperoleh lebih besar dari signifikansi $\alpha=0,05$. Dengan demikian $\mathrm{H}_{0}$ diterima dan $\mathrm{H}_{1}$ ditolak. Artinya, bentuk regresi keterampilan berpikir kritis adalah linier.

Uji Kolinieritas dilakukan untuk menguji ada atau tidaknya korelasi antarvariabel dependen dalam penelitian yang meliputi variabel pemahaman konsep IPA dan variabel keterampilan berpikir kritis. Berdasarkan hasil korelasi tersebut maka didapatkan nilai korelasi antarvariabel dependen sebesar 0,519. MANCOVA akan memberikan interpretasi yang terbaik jika koefisien korelasi bergerak diantara $r<0,6$. Berdasarkan Tabel 4.13 diperoleh koefisien korelasi pearson product moment antara variabel pemahaman konsep dengan keterampilan berpikir kritis sebesar 0,519.

\section{Menurut Arikunto} MANCOVA akan memberikan interpretasi yang terbaik jika terdapat korelasi yang tidak begitu besar dengan koefisien korelasi bergerak di antara $r<0,6$. Selain itu, Arikunto (2005) juga mengungkapkan bahwa penggunaan MANCOVA yang memiliki korelasi yang tinggi pada variabel dependen sangat tidak efektif. Dari hasil tersebut dapat disimpulkan bahwa uji MANCOVA dapat dilanjutkan.

Analisis statistik yang dilakukan berikutnya adalah analisis untuk menguji hipotesis penelitian. Pengujian hipotesis pertama menggunakan analisis multivariat.

Pengujian hipotesis I pengaruh model belajar ditemukan bahwa nilai-nilai statistik Pillai's Trace, Wilks' Lambda, Hotelling's Trace, dan Roy's Largest Root masing-masing dengan $F=16,580$ dan angka signifikansi masing-masing 0,001. Oleh karena angka signifikansi lebih kecil dari 0,05, maka hipotesis nol yang menyatakan " tidak ada pengaruh model belajar terhadap pemahaman konsep IPA dan keterampilan berpikir kritis siswa secara bersama-sama" ditolak. Jadi secara bersama-sama pemahaman konsep IPA dan kemampuan berpikir kritis siswa secara signifikan $(P<0,05)$ dipengaruhi oleh model pembelajaran.

Simpulan yang dapat ditarik adalah terdapat perbedaan yang signifikan antara pemahaman konsep IPA dan keterampilan berpikir kritis siswa, kelompok siswa yang belajar dengan menerapkan model pembelajaran berbasis masalah dengan menerapkan model pembelajaran konvensional. 
Hipotesis kedua dan hipotesis ketiga yang diajukan adalah dianalisis dengan MANCOVA. Hipotesis kedua dapat diuji berdasarkan Tabel Tests of Between-Subjects Effects skor PK, tampak nilai statistik $F=18,261$ dengan angka signifikansi 0,001. Angka signifikansi ini lebih kecil dari 0,05. diperoleh angka statistik $F$ sama dengan 18,261 dan angka signifikansi 0,001 $(\alpha<0,05)$. Jadi hipotesis $H_{0}$ ditolak, $H_{1}$ diterima. Simpulannya adalah terdapat perbedaan pemahaman konsep IPA antara kelompok siswa yang belajar dengan menggunakan model pembelajaran berbasis masalah dengan kelompok siswa yang belajar menggunakan model pembelajaran konvensional. Rata-rata pemahaman konsep IPA kelompok siswa yang belajar dengan menggunakan model pembelajaran berbasis masalah $\mathrm{M}=54,43$ dengan $\mathrm{SD}=3,641$ lebih besar dari ratarata kelompok siswa yang belajar dengan menerapkan model pembelajaran konvensional sebesar $M=49,34$ dengan $\mathrm{SD}=3,950$.

Hipotesis III Sumber pengaruh model pembelajaran (MP), terhadap nilai $\mathrm{KBK}$, tampak nilai statistik $F=22,272$ dengan angka signifikansi 0,001. Angka signifikansi ini lebih kecil dari 0,05 $(p<0,05)$. Simpulannya adalah setelah perlakuan dikontrol dengan kovariabel pemahaman konsep IPA dan keterampilan berpikir kritis awal, terdapat perbedaan keterampilan berpikir kritis siswa antara kelompok siswa yang belajar menggunakan model pembelajaran berbasis masalah dengan kelompok siswa yang belajar dengan model pembelajaran konvensional. Ratarata kemampuan berpikir kritis siswa kelompok siswa yang belajar model pembelajaran berbasis masalah sebesar $M=43,34$ dengan $S D=3,298$ lebih besar dari rata-rata kelompok siswa yang belajar dengan menerapkan model pembelajaran konvensional sebesar $M=38,13$ dengan $\mathrm{SD}=3,609$.

\section{SIMPULAN DAN SARAN}

Berdasarkan atas hasil penelitian dan pembahasan di atas dapat dikemukakan kesimpulan sebagai berikut.

1. Secara bersama-sama terdapat perbedaan pemahaman konsep IPA dan keterampilan berpikir kritis siswa yang signifikan antara kelompok siswa yang belajar dengan menerapkan model pembelajaran berbasis masalah (PBL) dengan siswa yang belajar dengan menerapkan model pembelajaran konvensional.

2. Secara bersama-sama terdapat perbedaan signifikan pemahaman konsep IPA siswa yang signifikan antara kelompok siswa yang belajar dengan menerapkan model pembelajaran berbasis masalah $(P B L)$ dengan siswa yang belajar 
Jurnal Teknologi Pembelajaran Indonesia

ISSN: 2615-2797(Print) | ISSN: 2614-2015 (Online)

Volume 9 Nomor 1 Tahun 2019

dengan menerapkan model pembelajaran konvensional. Yang artinya bahwa pemahaman konsep IPA antara siswa yang mendapat model pembelajaran berbasis masalah (PBL) jauh lebih baik dibandingkan dengan siswa yang mendapat model pembelajaran konvensional.

3. Secara bersama-sama terdapat perbedaan keterampilan berpikir kritis siswa yang signifikan antara kelompok siswa yang belajar dengan menerapkan model pembelajaran berbasis masalah $(P B L)$ dengan siswa yang belajar dengan menerapkan model pembelajaran konvensional. Yang artinya keterampilan berpikir kritis antara siswa yang mendapat model pembelajaran berbasis masalah ( $P B L$ ) jauh lebih baik daripada siswa yang mendapat model pembelajaran konvensional.

Berdasarkan hasil penelitian ini, maka dapat diajukan beberapa saran dalam upaya meningkatkan pemahaman konsep IPA dan keterampilan berpikir kritis siswa dalam pembelajaran.

1) Kepada guru, khususnya guru IPA, dalam proses pembelajaran di kelas disarankan menggunakan model pembelajaran berbasis masalah $(P B L)$ sebagai salah satu upaya untuk meningkatkan pemahaman konsep IPA dan keterampilan berpikir kritis yang pada akhirnya bermuara pada hasil belajar dan juga membelajarkan siswa untuk membuat keputusan yang tepat dalam menghadapi suatu masalah karena metode tiga langkah yang ditampilkan pada pendekatan model pembelajaran berbasis masalah ( $P B L)$.

2) Pengajar yang akan menerapkan model pembelajaran berbasis masalah $(P B L)$, dalam menyusun masalah yang diberikan kepada siswa haruslah lebih dikaitkan dengan fenomenafenomena yang dekat dan biasa dialami siswa setiap hari dan lebih terarah karena pertanyaanpertanyaan inilah yang menjadi inti pelaksanaan model pembelajaran berbasis masalah.

3) Perlu adanya penelitian lebih lanjut mengenai model pembelajaran berbasis masalah $(P B L)$, karena pada penelitian ini materi pembelajaran yang digunakan terbatas hanya pada pokok bahasan pengelolaan lingkungan, sehingga dapat dikatakan bahwa hasil-hasil penelitian hanya terbatas pada materi tersebut.

\section{DAFTAR RUJUKAN}

Akinoglu, O. \& Tandogan, R. O. (2007). The effect of problem-based active learning in science education on students academic achievement, attitude and concept learning. Eurasia Journal of Mathematics, Science \& Technology Education. 71-81. Tersedia pada 
http://www.ejmste.com/v3n1/EJMST

E v3n1. Diakses 8 oktober 2010.

Arikunto, S. 2002. Prosedur penilaian. Jakarta: Bumi Angkasa.

Arikunto, S. 2005. Manajemen penelitian. Jakarta: Rineka Cipta.

Arnyana, I. B. P. 2007. Strategi belajar mengajar. Singaraja: Universitas Pendidikan.

Bloom, B. S. (Ed). 1956. Taxonomy of educational objectives: The classification of educational goals. hand-book I: Cognitive domain, New York: Longman.

Bloom, B. S. 1979. Taxonomy of educational objectives, book 1 Cognitive Domain. London: Logman Group Limited.

Brooks, J.G. \& Martin G. Brooks. 1993. In search of understanding: The case for constructivist classrooms. Virginia: Association for Supervision and Curriculum Development.

Burrowes, P. A. 2003. A student-centerd approach to teaching general biology that really works: lord's constructivist model put to test. The American Biology Teacher. 65 (7): $491-501$.

Candiasa, I M. 2010a. Pengujian instrumen penelitian disertai aplikasi ITEMAN dan BIGSTEPS. Singaraja: Unit Penerbit Universitas Pendidikan Ganesha.

Candiasa, I M. 2010b. Statistik multivariate disertai aplikasi dengan SPSS. Singaraja: Universitas Pendidikan Ganesha. Carin, A. A. \& Barman, R, C. 1993. Teaching modern science. Sixth Edition New York: Mc. Millan Publishing Company.

Costa, A. L. 1985. Developing mind: A resource book for teaching thinking. Virginia: Association for
Supervision and Curriculum

Development.

Daryanto, H. M. 2005. Evaluasi pendidikan. Jakarta: Rineka Cipta.

Depdiknas, 2002. Rencana strategi departemen pendidikan nasional. Jakarta: Depdiknas.

Dewey, J. 2002. Pengalaman dan Pendidikan. Terjemahan John de Santo. Yogyakarta: Kepel Press.

Dewi Kartika, M., Santyasa, W., \& Warpala, W. 2014. Pengaruh pembelajaran berbasis masalah terhadap pemahaman konsep fisika dan keterampilan berpikir kritis siswa. E-Jurnal Program Pascasarjana Universitas Pendidikan Ganesha. Program Studi Teknologi Pembelajaran 4(1). Terdapat pada http://pasca.undiksha.ac.id/ejournal/index.php/jurnal tp/article. Diakses 21 Nopember 2014.

Dewi, P. S. U., Sadia, I W., \& Suma, K. 2014. Pengaruh model problem based learning terhadap kemampuan pemecahan masalah Fisika melalui pengendalian bakat numeric siswa SMP. E-Journal Program Pascasarjana Universitas Pendidikan Ganesha Program Studi IPA. 4(1).

Dzaki, M. F. 2009. Teori Belajar Konstruktivis dalam Pembelajaran Fisika. Artikel. Tersedia pada penelitiantindakankelas blogspot.com/2009/03/ teorikontruktivisme html.

Ennis, R. H. 1985. Goal critical thinking curriculum. Dalam: Costa, A. L (Ed): Developing Minds: A resourse book for teaching thinking.

Etherington, M. 2011. Investigative primary science: A Problem-based learning approach. Australian Journal of Theacher Education. 36(9): 36-57. Tersedia pada 
http://ro.ecu.edu.au/ajte. Diakses September 2011.

Faizah, Miswadi, S. S., \& Haryani, S. 2013. Pengembangan perangkat pembelajaran berbasis masalah untuk meningkatkan soft skill dan pemahaman konsep.Jurnal Pendidikan IPA Indonesia http://journal. unnes.ac.id/nju/index.php/jpii. Program Studi Pendidikan IPA, Program Pascasarjana, Universitas Negeri Semarang 2(2). Dipublikasikan: Oktober 2013.

Fogarty, R. \& McTighe, J. 1993. Educating teachers for higher order thinking: The three-story intellect. Dalam Donmoyer, R. \& Merryfield, M. M (Eds.): Theory into practice: Teaching for higher order thinking. 32(3). 161-169.

Gardner, H. 1999. Intelligence reframed: Multiple intelligences for the 21th century.New York: Basic Books.

Gregory, R. J. 2000. Psychological testing (History Principles and Aplications), Bonston, Allyn and Bacon.

Krulik, S \& Rudnick, J. A. 1996. The new sourcebook for teacing reasoning and problem solving in Junior and Senior High School. Boston: Allyn and Bacon.

Kunandar. 2007. Guru Profesional: Implementasi Kurikulum Tingkat Satuan Pendidikan (KTSP) dan persiapan menghadapi Sertifikasi Guru. Jakarta: PT Raja Grafindo Persada.

Montgomery, D. C. 1991. Design and analysis of experiment. Third edition. New York: John Wiley \& Sons.

Montgomery, D. C. 1996. "Pengantar Pengendalian Kualitas Statistik". Yogyakarta: Gadjah Mada University Press.
Mulyasa. 2005. Menjadi Guru Profesional. Bandung: Rosda Karya.

Nur, M. 2002. Buku Pedoman keterampilan proses dan hakekat sains. Surabaya: University Press.

Nurkencana, I.W \& Sunartana, P. 1990. Evaluasi Keterampilan berpikir kritis.

Nurkencana, I W, \& Sunartana P.P.N. 1992. Evaluasi Belajar. Surabaya: Usaha Nasional.

Purwanto, 2004. Psikologi Pendidikan Bandung. Remaja Rosdakarya.

Purwanto, (ed). 2005. Jejak Langkah Perkembangan Teknologi Pendidikan di Indonesia, Jakarta: Pustekkom-Depdiknas.

Rosita, A., Sudarmin., \& Marwoto, P. 2014. Perangkat pembelajaran problem based learning berorientasi green chemistry materi hidrolisis garam untuk mengembangkan soft skill konservasi siswa. Jurnal Pascasarjana Universitas Negeri Semarang. Pendidikan IPA Indonesia. 3(2). (Dipublikasikan: Oktober 2014).

Sagala, S. 2007. Konsep dan Makna Pembelajaran. Bandung: Alfabeta.

Saleh, S. 2011. The level of B. Sc Ed students' conceptual understanding of Newtonian physics. International Journal of Academic Research in Business and Social Sciece. 1(3): 249-256.

Santyasa, I W. 2003. Pendidikan, Pembelajaran, dan Penilaian Berbasis Kompetensi. Makalah dalam seminar akademik himpunan mahasiswa Jurusan Fisika IKIP Negeri Singaraja, tanggal 27 Februari 2003, di Singaraja. 
Santyasa, I W. 2004 (a). Pengaruh model dan seting pembelajaran terhadap remidiasi miskonsepsi, pemahaman konsep, dan hasil belajar siswa pada siswa SMU. Disertasi (tidak diterbitkan). Universitas Negeri Malang Program Pasca Sarjana Program Studi Teknologi Pembelajaran.

Santyasa, I. W. 2004 (b). Model Problem solving dan reasoning sebagai alternatif pembelajaran inovatif. Makalah. Disajikan dalam Konvensi Nasional Pendidik Indonesia (Konaspi) V. Tanggal 59 Oktober 2004 di Surabaya dengan tema "menata pendidikan nasional yang bermutu untuk membangun kualitas kehidupan dan peradaban bangsa.

Santyasa, I W. 2007. Model-model pembelajaran inovatif. Makalah. Disajikan dalam pelatihan tentang Penelitian Tindakan Kelas bagi guru-guru SMP dan SMA di Nusa Penida, tanggal 29 Juni s.d 1 Juli 2007.

Santyasa, I W. 2011. Pembelajaran inovatif. Buku Ajar. Singaraja: Universitas Pendidikan Ganesha.

Santyasa, I W. 2012. Pembelajaran inovatif. Buku Ajar. Singaraja: Universitas Pendidikan Ganesha.

Seels, Barbara B. \& Richey, Rita C. 2000. Instructional technology, The Definition and Domains of the Field. Terjemahan Dewi $\mathrm{S}$ Prawiradilaga, R. Rahardjo, Yusufhadi Miarso. Jakarta: IPTPI \& LPTK.

Semerci, C. 2005. The influence of the critical thinking skills on the students' Achievement. Pakistan Journal of Social Sciences, 3(4), 598-602.

Slavin, R. E. 1994. Educational psychology: Theory and practise.
Fourth Edition. Massachusetts: Allyn and Bacon.

Slavin, R. E. 1997. Educational Psychology Theory, Research, and Practise, Fifth Edition. Massachusetts: Allyn and Bacon Publishers.

Somantri, A. 2006. Aplikasi statistik dalam penelitian. Bandung: Pustaka Setia.

Suastra, I W. 2009. Pembelajaran sains terkini. Singaraja: Universitas Pendidikan Ganesha.

Sudewi, N. L., Subagia, I W., \& Tika, I N. 2014. Studi komparasi penggunaan model pembelajaran problem based learning (pbl) dan kooperatif tipe group investigation (gi) terhadap hasil belajar berdasarkan taksonomi Bloom. EJournal Program Pascasarjana Universitas Pendidikan Ganesha Program Studi IPA 4(1). Program Studi Pendidikan IPA, Program Pascasarjana Universitas Pendidikan Ganesha Singaraja, Indonesia.

Sudjana, Nana. 2001. Penilaian Hasil Proses Belajar Mengajar. Bandung: Remaja Rosda Karya.

Sudjana, Nana. 2007. Teknologi Pengajaran. Bandung: Sinar Baru Algesindo.

Sugiono. 2010. Metode penelitian kualitatif kuantitatif, $R$ \& $D$. Bandung: Alfabeta.

Sugiyono. 2011. Statistik untuk penelitian. Bandung: Alfabeta.

Sunariyati, N. L., Gede Agung, A. A., \& Dantes, N. 2014. Pengaruh model pembelajaran berbasis masalah (problem based learning/PBL) terhadap hasil belajar, keterampilan berfikir kritis dan sikap ilmiah dalam pembelajaran fisika pada siswa kelas XI IPA SMA Negeri 1 Kuta tahun 
pelajaran 2014/2015. Program Studi Administrasi Pendidikan, Program Pascasarjana Universitas Pendidikan Ganesha Singaraja, Indonesia.

Suparman, M. Atwi, \& Aminudin Zuhairi. 2004. Pendidikan Jarak Jauh Teori dan Praktik. Jakarta: Universitas Terbuka.

Suparno. P. 1997. Filsafat kontruktivisme dalam pendidikan. Yogyakarta: Kanisius.

Suparno. P. 2001. Filsafat kontruktivisme dalam pendidikan. Yogyakarta: Kanisius.

Warpala, I W. S. 2006. Pengaruh pendekatan pembelajaran dan strategi belajar kooperatif yang berbeda terhadap pemahaman dan keterampilan berpikir kritis dalam pembelajaran IPA SD. Disertasi (tidak diterbitkan). Universitas Negeri Malang Program Pasca Sarjana Studi Teknologi Pembelajaran. 